\title{
UNION PARTICIPATION IN JAPAN: DO WESTERN THEORIES APPLY?
}

\author{
SAROSH KURUVILLA, DANIEL G. GALLAGHER, JACK FIORITO, \\ and MITSURU WAKABAYASHI*
}

\begin{abstract}
This study investigates the validity in Japan of union participation models developed in North America. The results of ordinary least squares analysis suggest that members' participation in unions is positively related to many of the same factors in Japan as in North America: for example, length of union membership, pay, dissatisfaction regarding pay and working conditions, degree of interaction with others in the work group, and perceptions of the union's effectiveness and its democratic character. Some findings at odds with those of Western studies, however, are that older workers and better-educated workers are less (rather than more) likely than others to actively participate, and job status is unrelated (rather than positively related) to participation.
\end{abstract}

I $\mathrm{s}$ industrial relations knowledge generalizable across national boundaries, or are cultures so different that any industrial relations theory must be considered culture-specific? This question is one of the most fundamental in the field, but it is, as yet, largely unanswered. This study focuses on the cross-cultural applicability of models concerning one aspect of industrial relations: the determinants of union

\footnotetext{
* Sarosh Kuruvilla is Assistant Professor of Industrial and Labor Relations at Cornell University, Daniel G. Gallagher is Professor of Management at James Madison University, Jack Fiorito is Associate Professor of Industrial Relations and Human Resources at the University of Iowa, and Mitsuru Wakabayashi is Professor of Educational Psychology at Nagoya University. The authors thank Mamoru Sano for helping to arrange union cooperation for the study, Michio Fujiwara and Frank Schmidt for helpful suggestions, and Anil Arya for research assistance.

Requests for details of computer programs used to generate the results in this paper, and for other pertinent information regarding the data and measures used, should be addressed to Professor Sarosh Kuruvilla, 156 Ives Hall, Cornell University, Ithaca, NY 14851-0952.
}

participation. Specifically, we investigate the validity in Japan of models of union participation that were developed primarily in North America.

During America's "Golden Age" of union governance research in the 1950s (see Strauss 1977), member participation in union activities received considerable attention. Recently there has been a resurgence of interest in participation, with new perspectives and increased methodological rigor. One important methodological change has been the increasing use of multivariate analysis, which has largely replaced bivariate computations (McShane 1986a, 1986b; Huszczo 1983; Kolchin and Hyclak 1984). Most of the research on union participation, however, has been limited to North America and Great Britain (Nicholson, Ursell, and Blyton 1981).

This paper examines the determinants of individual participation in Japanese unions. Japanese industrial relations has some unique characteristics-senioritybased wage and promotion systems, enter- 
prise unionism, and lifetime employment, for example-that lend such a study particular interest. ${ }^{1}$ In addition, the generally close cooperation between Japanese unions and employers has received much attention in the American press, usually being depicted as a reason for Japan's economic success. Union density levels in Japan are fairly high compared to U.S. levels, and have remained in the range of $29 \%$ to $34 \%$ over the past 10 years (Troy and Sheflin 1985). Given what we know about its people, culture, and industrial relations system, Japan provides an interesting setting for examining the causes of union participation and the generalizability of Western-style participation models. Furthermore, membership support and participation in enterprise unions is critical to the achievement of union objectives in Japan, especially in the context of changes in the Japanese economy as a result of increased foreign competition, shifting patterns of protectionism, and shrinking domestic employment opportunities. Nonetheless, unlike in the West, in Japan there has been little research on union participation, and no empirical studies on individual participation in Japan have been reported in English or Japanese.

We examine the extent to which participation results obtained in the West can be replicated under the unique Japanese conditions noted above. In order to facilitate this comparison, survey instruments developed primarily in North America were adapted for use in this study. Our measure of participation reflects items used in previous Western studies that are relevant in the Japanese context, including union voting, committee work, campaign

\footnotetext{
${ }^{1}$ These traits do not characterize all Japanese employment, but mainly the large establishments in the manufacturing sector. The most unusual features of the Japanese industrial relations system, Mills noted, "arise from the duality of the Japanese economy. . . . Japan's economy has two sectors: one made up of large firms that are technically advanced and another made up of many small firms with very inefficient production processes" (1986:518-19). Furthermore, Okubayashi (1986), among others, has noted that the lifetime employment system in Japan's large-scale enterprises has eroded in recent years. Also see Taira and Levine (1985).
}

work, meeting attendance, and reading union newsletters. The study was conducted using responses by over 6,600 Japanese union members from 18 companies in 32 sites.

\section{Literature Review and Hypotheses}

At least three distinct perspectives have motivated research on union participation. First, participation has been viewed as an indicator of internal union democracy. Second, some researchers have attempted to identify characteristics of union activists. Finally, and most recently, administrative participation (such as committee service and office-holding), as opposed to passive participation (such as meeting attendance), has been stressed as an activity vital to the organizational effectiveness of unions (McShane 1986a).

The heterogeneity of participation studies also stems from varying theoretical perspectives. Klandermans (1986:189) noted that from a psychological perspective, three distinct theories have guided research: "The first approach points to dissatisfaction as the cause of participation [frustration-aggression theory], the second to the perceived costs and benefits of participation [rational choice theory], and the third to the social context of individuals [interactionist theory]." These diverse orientations, coupled with alternative disciplinary perspectives, have resulted in studies that differ in the participation measures and antecedent or correlate measures used as well as in other respects. ${ }^{2}$

Below, we summarize the literature in terms of hypotheses and empirical results for specific independent variables. Particular attention is devoted to features of the Japanese employment system that are germane to the relationships discussed. Based on this analysis, hypotheses are formulated. For ease of presentation, we have grouped previous literature and our

\footnotetext{
${ }^{2}$ Reviews by Perline and Lorenz (1970), Spinrad (1960), and Strauss (1977) summarize earlier North American literature, and Klandermans (1986) adds an international perspective.
} 
hypotheses into four broad categories: demographic and background characteristics, job-related variables, union attitude variables, and group associations.

\section{Demographic and Background Characteristics}

Early North American studies tended to identify factors associated with high levels of participation and draw demographic distinctions between active and nonactive members. Generally, active members were found to be male, older, higher paid, married, with pro-union family backgrounds, members of an ethnic minority, and long-term members (Spinrad 1960; Perline and Lorenz 1970; Tannenbaum and Kahn 1958).

One criticism of these early studies has been that they relied entirely on bivariate computations. Anderson (1979) pointed out that within a multivariate design many of these demographic features were not significantly related to union participation. In contrast, he found role-type characteristics to be more important determinants. Other studies using multivariate designs found that education was positively related to participation (Kochan 1978; Hoyman and Stallworth 1987; McShane 1986a). Seniority (tenure) was also found to be a significant and positive predictor of participation (Kochan 1978; Strauss 1977). British studies tend to complement North American studies in finding that job tenure, educational attainment, and parental union orientation are related to participation within white-collar unions (Nicholson, Ursell, and Blyton 1981). Nicholson et al. also noted that men were more prone to participate than women, a finding supported by studies in Sri Lanka and Malaysia (Ahmed 1984) and Sweden (Sundström 1982).

In Japan, Cook and Hayashi (1981) noted that women are rarely visible in positions of union leadership, even in unions with large female memberships such as in textiles, telecommunications, education, department stores, and government service. They noted further that although most unions have a women's division, women have limited standing within the union executive body. They found that marriage and children, especially, inhibit greater female participation in industry and union leadership, since bringing up children is seen primarily as a "female responsibility." Consequently, we expect that women will be less prone than men to participate in Japanese unions.

In the West, no significant multivariate relationship was found between the number of children and union participation. In Japan, more pronounced sex-role stereotyping and the scarcity of commercial childcare (Hayashi 1985) lead us to expect that women with children will be especially unlikely to participate. This hypothesis is reflected in an interaction term (MOTHER) that is the product of gender and a dummy variable for the household presence of children age 12 and under. A negative effect is predicted.

As in the West, there is reason to believe that organization tenure, age, pay, and education will be determinants of union participation in Japan, particularly in view of the seniority $(n e n k \bar{o})$ wage and promotion system. A primary feature of the $n e n k \bar{o}$ system is the determination of individual wages according to length of service, with little relation to individual performance and job (Sano 1977). Sano also noted that the nenko system is decreasing in popularity, but we are still guided by Cole's (1970) observation that union leaders are more likely to be drawn from more senior and higher-paid employees. We include years of union membership (MBRYRS) and organizational tenure (ORGTEN), expecting both to be positively related to participation.

Pay could represent many things, especially in the Japanese nenko system, where strong correlations with seniority would be expected. Since seniority is captured more directly by age and union membership tenure variables in the model, the pay variable (SALARY) is viewed as another measure of one's stake in the job, as Strauss's (1977) concept suggested. We expect SALARY to have a positive impact on participation.

A positive effect is also expected for education (EDUC). Education has been 
found to be positively associated with participation in other empirical studies (for example, McShane 1986b), possibly because it enhances self-perceptions of competence and hence willingness to assume the higher profile of a union activist.

\section{Job-Related Characteristics}

A persistent finding in U.S. studies is that job status tends to be associated with higher levels of participation. (Spinrad 1960; Perline and Lorenz 1970; Strauss 1977; McShane 1986b.) We expect that in Japan's seniority-based wage and promotion system (nenkō joretsu seido), members with higher job status and seniority will be more likely to be union leaders. To capture status effects, we include a dummy variable (STATUS) equal to one for assistant foreman through manager and equal to zero for rank-and-file employees.

Although we expect STATUS to be positively related to participation, we also believe that status must be carefully interpreted. Van Helvoort (1979) noted that in Japan there are dual hierarchies in one status system in most organizations. One is the ordinary line hierarchy; the other, known as the tōkyu shikaku seido, is a kind of qualification system that places employees along the hierarchy of grade $(t \bar{o} k y \bar{u})$ according to ability qualifications (shikaku), as determined by their level of knowledge, proficiency, experience, skill, general capabilities, and seniority. Within this system, shikaku is directly tied to the wage level through the $t \bar{o} k y \bar{u}$, whereas a position in the line hierarchy is related to decision-making authority.

The North American literature suggests that job satisfaction is negatively related to union participation (McShane 1986a). Two studies that distinguished between "extrinsic" and "intrinsic" job satisfaction, however - that is, between satisfaction with pay and other extrinsic aspects of the job, on the one hand, and satisfaction with the nature of the job itself, on the otherfound a positive relationship between intrinsic satisfaction and participation.
(Huszczo 1983; Nicholson, Ursell, and Lubbock 1981.)

There is a considerable amount of job dissatisfaction in Japan, contrary to popular Western perceptions. The Japanese Labor Ministry's 1974 General Survey on Worker Welfare, conducted among 47,000 workers in private industry, indicated that $48 \%$ of the respondents reported dissatisfaction with work in general (Koshiro 1980). Evidence also indicates that Japanese workers depend on the union to defend workers' interests and confront management on various issues. Cole's (1970:125) finding that even sophisticated and articulate noncommunist workers strongly and actively supported communist elements in union leadership lends some support to the idea that Japanese workers depend on unions. This evidence is reinforced by a 1976 survey that asked 30,000 Japanese union members to evaluate their unions: $62 \%$ of the respondents perceived unions to be instrumental and of central importance for protecting living standards and working conditions (Bandō 1981:37). Thus, the necessary ingredients for a relationship between job satisfaction and union participation-job dissatisfaction and instrumental views of unionsare present.

Studies conducted in the West have found a negative relationship between extrinsic job satisfaction and union participation, consistent with what Klandermans (1986) called frustration-aggression theory. Consequently, we expect a negative relationship between extrinsic job satisfaction (EXTSAT) and union participation. Conversely, as posited by McShane (1986b) and Nicholson, Ursell, and Lubbock (1981), a positive relationship is expected between intrinsic job satisfaction (INTSAT) and participation. Klandermans' (1986) "rational choice theory," which encompasses Strauss's (1977) "stake in the job" notion, may be more pertinent than frustrationaggression theory in considering intrinsic job satisfaction.

We include another variable, ease of exit (EASEEXIT), in view of the lifetime employment system that is widely practiced in most large-scale Japanese compa- 
nies. The EASEEXIT measure consists of the response to a question regarding the perceived ease of finding alternative employment. Oh (1976) noted that the lifetime employment system (shüshin koȳo) imposes considerable restrictions on interorganizational mobility, since exiting an organization essentially means loss of this benefit. Perceived ease of interorganizational mobility implies a lesser job "stake," hence a smaller payoff to participation, and thus less activism. Consequently, ease of exit should have a negative effect on participation.

\section{Union-Related Variables}

Anderson (1979) indicated that worker attitudes toward the local union were important determinants of participation. Later studies (Huszczo 1983; McShane 1986b) have also supported this view. Attitudinal measures have included attitudes toward unions and leaders (Glick, Mirvis, and Harder 1977; Huszczo 1983), interest in union business (McShane 1986a), and perceived value of unions (McShane 1986a; Kolchin and Hyclak 1984; Anderson 1979). Perline and Lorenz (1970) noted that workers who identify with union functions are more likely to participate. Also, the perceived informativeness, helpfulness, and democratic character of the union leadership were related to participation (Lassewell, Burma, and Aronson 1965; Tannenbaum and Kahn 1958). In Britain, findings by Nicholson, Ursell, and Blyton (1981) strongly suggest that attitudes toward unions affect union participation more strongly than either job characteristics or job dissatisfaction.

In a cross-national study conducted in the United States, Italy, Argentina, and India, Form (1973:221) found that a favorable attitude to one's own union was positively related to participation. In Japan, Cole (1970) noted that since enterprise union leaders come from within the firm, it is possible to develop strong bonds between leaders and rank and file. Cole also argued that the image and perceived capability of the union leader have an important effect on the extent of active support for union activities. Consequently, we expect attitude toward union leaders (ATTULDRS) to be positively related to participation. This variable measures the degree to which members believe the union makes reasonable demands and has member support and the degree to which they perceive union leaders as effective and interested in member welfare.

As noted earlier, Western research indicates that identification with the union is a strong predictor of participation. We include identification with the union (IDUNION), a multi-item indicator, in the analysis, and we expect that it will be positively related to participation. This variable includes measures of the correspondence between the member's and the union's values, the member's interest in the union's fate, and the member's willingness to discuss job problems with union leaders.

McShane (1986a) and Kolchin and Hyclak (1984) reported a positive relationship between the perceived value of unions and participation. Cole (1970) noted that workers depend on the union to protect their interests. Thus, the concept of "payoff to participation" (Strauss 1977) again appears relevant in the Japanese context. Instrumentality (INSTRUMT) is a multi-item scale that reflects the perceived instrumentality of the union, and we expect this variable to be positively related to participation. INSTRUMT includes measures of the degree to which members believe that unionism has benefits for the worker, that the union provides a useful communication channel with the employer, that continued membership is desirable, and that much can be gained by staying with the union.

\section{Group Associations}

One criticism of earlier studies of participation in the West was that they did not emphasize social relationships at work and integration into the occupational community (Nicholson, Ursell, and Lubbock 1981). The general hypothesis here is that members who have a greater need for affiliation within and are socially well 
integrated into the occupational community are more likely to be active in the union (Anderson 1979; Glick et al. 1977; Kolchin and Hyclak 1984:257; McShane 1986a; Strauss 1977). This expectation accords with what Klandermans (1986) called "interactionist theory."

To understand this phenomenon in the context of Japanese union participation, one must look to personal relationships at work, which are influenced by emotion and customs. Hanami (1979) noted a strong degree of amae or dependence on others (on peers, superiors, or one's group) in Japanese society that extends to the workplace. These strong relationships account for a high degree of solidarity and conformity within any work group (Vogel 1971). Shirai (1983) argued that the uniqueness of Japan lay not so much in its allegedly peculiar institutions, such as lifetime employment, seniority wages, and enterprise unions, as in the "fourth pillar": in essence, the social norms within the enterprise. He suggested that there is a "great degree of enterprise consciousness. For most Japanese workers, the firm in which they work is a community with which they strongly identify. It is at their workplace that they communicate and feel solidarity with each other" (1983:4). This consideration suggests that Japanese union members would be highly integrated into the union when they feel they are members of a cohesive work group.

In view of the amae feeling or strong group consciousness among the Japanese (Hanami 1979), we employ a multi-item measure of interaction with group members and social integration at work (wKGROUP) to test the importance of group associations in influencing participation. This variable includes measures of group cohesion and support and measures of the extent to which members feel accepted and trusted, make personal sacrifices, and extend extra effort for the betterment of the work group. We expect this variable to have a positive effect on union participation.

\section{Control Variables}

Strauss (1977) noted that the character- istics of the union-management relationship may influence participation. A major advantage of enterprise unions is that they facilitate a close cooperation between management and union. Furuya (1980) and Shirai (1983) observed that in most cases, lower-ranking supervisors with a strong influence at the workshop level are elected union officials, providing intermediate-level support for a trusting relationship between labor and management. This kind of trust is possible when supervisors and workers belong to the same union, and it may also account for the high levels of dual allegiance noted by Odaka (1975). Therefore, we expect the quality of the union-management relationship (QUMREL) to positively influence participation.

Another potentially interesting question is whether the size of the union influences participation. As a union grows larger, members' involvement tends to be reduced, since the direct contact between leaders and members may decrease (Huszczo 1983; Strauss 1977). Shirai (1983: 119) noted that membership in enterprise unions in Japan is limited to all regular employees of the enterprise. As noted by Naitō (1983), most enterprise unions are small, facilitating a close interaction between leaders and rank and file. The union size in our sample of 18 companies ranges from 403 to 63,085 , a degree of variation that might yield a size effect. Union size is measured by the log of the number of members in the union (LNUSIZE), and a negative relationship with participation is predicted. ${ }^{3}$

A final control variable (MPLANT) reflects whether workers are located in the main plant of the organization or at other plants. It is likely that a worker in a large primary plant will be closer to the center

\footnotetext{
${ }^{3}$ The use of the log transformation of size was motivated by theoretical considerations and the superior results obtained in other studies using this form. On a theoretical level, Abdel-khalik (1988) noted that the log of employees approximates the number of levels of hierarchy in organizations. Blau (1970) and Dewar and Hague (1978) reported empirical results showing that the log of size generally is more strongly related to various organizational measures than is size.
} 
of union activity than workers in small satellite plants, and thus more involved in or more immediately aware of many union decisions and activities. Consequently, we expect that workers in the main plant will be more likely to participate than workers in other plants.

\section{Participation in Japanese \\ Enterprise Unions}

Research on member participation in Japanese enterprise unions is scant, but the available information suggests that such participation is extensive and vital to the union's operations. As Strauss (1977) noted, union participation should be examined in terms of both formal provisions and informal arrangements. In Japan, evidence from both levels stresses participation.

At the formal level, Japanese law requires at least annual membership meetings and annual election of union officers by secret ballot (Ayusawa 1962:51). Also, most union constitutions place considerable limitations on union executives' authority (Naitō 1983:152). In addition, union officials retain their employee status in the company and revert to their former positions upon leaving elected union offices (Naitō 1983:147). There is thus less of a tendency in Japan than in the West for a union "officialdom" to develop.

The formal union structure and procedures in Japan reflect and reinforce a strong egalitarian norm at the informal level. Shirai (1983:129) noted that the Japanese precept of consensual decisionmaking applies to unions as well as firms. Coupled with Japanese "groupism" and the relatively small size of most enterprise unions, this "unconditional egalitarianism" (Naitō 1983:154) produces active and influential member participation. Most enterprise unions, like U.S. locals, are small enough to bring all members together for general meetings, and such meetings are frequent (Naitō 1983). Consequently, formal and informal circumstances combine to promote extensive member participation in Japan; Naitō even suggested that "administrative effi- ciency seems to have been unduly sacrificed to popular control" (1983:154).

\section{Measurement of Participation}

Union participation has been measured in various ways in the literature. Most studies have used a composite (multi-item) index of behavioral participation in various union activities, but among these studies, some have used more diverse activities to make up the index than have others (Hoyman and Stallworth 1987; Huszczo 1983). Typically, the activities investigated include attending meetings, actively participating at meetings (making speeches, motions, and so on), holding union office, serving on committees, voting in elections and on strike issues, working on union campaigns, and reading union newsletters. A few studies have used single-item measures (for example, Chacko 1985).

More recently, some observers have speculated that participation is a multidimensional phenomenon (McShane 1986b; Nicholson, Ursell, and Blyton 1981; Portwood, Pierson, and Schmidt 1981). Using factor analysis, McShane (1986b) identified three different forms of participation: "administrative participation" (for example, acting as a delegate to a convention or a member of union committees), "voting participation" (for example, voting in the latest election or casting a strike vote), and "meeting participation" (attending meetings). His results suggested that the determinants of these forms of participation are somewhat different. Nicholson, Ursell, and Blyton (1981) also found that different union activities have somewhat dissimilar antecedents.

Partly because little research has been done on union participation in Japan, in this study we investigate broad patterns rather than specific dimensions of participation. The dependent variable is a multi-item index of participation that includes items on attending union meetings, voting in union elections, reading union publications, working in elections and campaigns in support of union goals, 
and working on union committees. (An appendix available from the authors provides full descriptions of items). A factor analysis on these participation-related items indicated one overall participation factor, in contrast to McShane's (1986b) results. ${ }^{4}$ The reliability of our overall index was found to be at a satisfactory level ( $\alpha=$ $.65)$, and higher than that for specific subdimensions of participation, two of which were single-item measures and hence not very reliable. All the subdimensions of participation were also significantly correlated with each other. ${ }^{5}$

\section{Data and Methods}

The data were collected through questionnaires administered to a crosssectional sample of unionized workers at 32 sites in 18 different companies in the heavily industrialized area of Nagoya, Japan. The original questionnaire was

\footnotetext{
${ }^{4}$ A factor analysis on the five participation items included in the composite yielded a single dominant factor with an eigenvalue of 2.12. The second factor's eigenvalue was .87 . Factor loadings were relatively "flat," from .57 to .70 . The dominant factor accounted for $42 \%$ of the common variance. Principal components methods were used.

${ }^{5}$ Subdimensions of participation in accordance with McShane's (1986a) scheme were created out of the five items included in the overall index of participation. Administrative participation (ADMN, $\alpha$ $=.51$ ) consisted of two items pertaining to working in union elections, campaigns, and committees, whereas voting participation (voTe) and meeting participation (MEET) were comprised of single items. Single-item scales are, of course, unreliable on theoretical and intuitive grounds, but there is no direct way of assessing their reliability absent additional parallel items. The raw correlations among the subdimension scales range from .245 to $.305(\mathrm{p}<.001)$.
}

We estimated the empirical model for each of the three subdimensions as a further check on the dimensionality issue, and found that the results did not differ substantially across the different subdimensions. (These results are available from the authors on request.) Given this finding and the low reliability of single-item measures, the empirical evidence provides strong support for the use of the overall five-item participation scale. In addition, since our study is the first to empirically examine union participation in Japan, we feel it is better to use an overall index for comparability purposes, rather than the subdimensions, which are better suited for use in "second generation" research. translated from English by the Japanese co-author. Translation-retranslation, or "back-translation," was used to check the accuracy of the original English-toJapanese translation. An additional set of items concerning work group relations (the basis for the WKGROuP variable), which were Japanese in origin, was added to the original questionnaire due to the importance of this factor in the Japanese context. ${ }^{6}$ A total of 9,459 questionnaires were distributed to permanent full-time employees ("regular workers") who were also union members. These questionnaires were sent to the executive branch of each enterprise union in the sample along with a letter from the union president stating that the study was being conducted solely for scientific and academic reasons. At the shopfloor level, branch union officials helped distribute the questionnaires to all union members. The questionnaires were returned in sealed envelopes (for anonymity) to the union office. A total of 7,390 usable responses were returned (a return rate of $78 \%$ ). After case-wise deletions for missing values, 6,651 cases were available for the analysis.

The respondents were from the largescale industrial sector, working in electrical, electronic, automotive, and auto ancillary firms. These firms, although they are not representative of Japanese industry as a whole, are reasonably representative of large-scale manufacturing companies of the kind that have received so much attention in the world press in recent years. Two of the 18 enterprise unions in this sample were independent unions; the others were affiliated to larger industrial unions such as the Confederation of Japan Automobile Workers' Unions, the Japanese Federation of Electrical Machinery Workers' Unions, the Japanese Federation of Metal Industry Unions, the National Trade Union of Metal and Engineering

\footnotetext{
${ }^{6}$ As evidence of the general applicability to Japan of the constructs and measures examined, the factor structures for each of the instruments in the questionnaire were quite similar to those found in the West. Details are available from the authors on request.
} 
Workers, and the Federation of AllToyota Workers' Unions. In addition, most of the unions were also affiliated to national federations such as Sōhyō, Dōmei, and Chūritsu Rōren.

Ordinary least squares regression was used to estimate the effects of various independent variables on union participation. A complete list of the variables used and definitions with descriptive statistics are provided in Table 1.

\section{Results}

The repression results in Table 2 provide support for most of the hypotheses. Most predictors obtained significance with the expected signs, suggesting the general applicability of a Western-style participation model. There are, however, some notable surprises in the results.

Virtually all the demographic variables were strong predictors of participation. Union tenure, organization tenure, and pay were positively related to participation, in accordance with our expectations. ${ }^{7}$ Contrary to our expectations, the presence of young children was positively related to participation, and gender per se was not significantly related to participation. The interaction between gender (being female) and the presence of young children, however, was significant with the expected negative sign, a result that is consistent with the notion that women have primary responsibility for childcare in Japan. ${ }^{8}$ Education was negatively related to participation, contrary to our expectations, and age showed a negative effect, indicating

\footnotetext{
${ }^{7}$ ORGTEN and MBRYRS were highly correlated $(r=$ .958 ). Consequently, we estimated the model with ORGTEN and MBRYRS, alternately, dropped from the list of independent variables. Both variables yielded positive and significant effects in all specifications, and results for other variables were insensitive to the presence or absence of these two variables.

${ }^{8}$ The presence of strong sex-role stereotyping in Japan is also supported indirectly by the fact that our sample contains very few mothers of young children. Although our sample was almost $18 \%$ female, less than $2 \%$ of the sample were mothers of young children. That is, only 89 of 1,166 women (less than $8 \%$ ) in the final sample reported the presence of children age 12 and under.
}

that older workers tend to participate less, holding tenure constant.

Among the job-related variables, only extrinsic satisfaction (EXTSAT) was significantly related to participation. The negative relationship between extrinsic satisfaction and participation is consistent with our hypotheses and with Western results. In Klandermans' terms, this finding may be viewed as support for frustrationaggression theory. Intrinsic satisfaction (INTSAT) was found to have no relationship to participation, contrary to our hypothesis. Neither was the perceived ease of finding alternative employment (EASEEXIT) significantly related to participation.

The job status variable was not significant. ${ }^{9}$ As noted earlier, status effects in Japan may be complicated by the dual status system. All of the union attitude variables obtained the expected signs and were highly significant. Union participation was positively related to positive attitudes toward union leaders (ATTULDRS), identification with the union (IDUNION), and views of the union as instrumental (INSTRUMT). These results strongly underscore the importance of the union itself in engendering union participation.

The workgroup interaction variable (wKGROUP) was found to be strongly and positively related to participation, consistent with our hypothesis. This result, which confirms the influence of amae in Japanese workplaces, is also consistent with the interactionist theories noted by Klandermans (1986).

The control variables yielded unsurprising results. As expected, the quality of union-management relations positively affected participation, and union size was negatively related to participation. Consistent with our hypothesis, it was found that union members who worked in the main plants of the organization were more likely to participate in union activity than were union members at satellite plants.

\footnotetext{
${ }^{9}$ We also estimated the model with separate dummy variables for each of the five higher-level jobs subsumed in the status variable. None of these dummies was significant, and their joint impact was significant at only the $p<.11$ level.
} 
Table 1. Variable Definitions and Descriptive Statistics.

\begin{tabular}{|c|c|c|c|}
\hline Variable & Description & Mean & Std. Dev. \\
\hline PARTIC & $\begin{array}{l}\text { A 5-item 5-point scale measuring participa- } \\
\text { tion in union activity (e.g., attending meet- } \\
\text { ings, voting in union elections, reading union } \\
\text { publications, and working in union elections, } \\
\text { campaigns, and committees) }(\alpha=.65)\end{array}$ & 3.061 & .823 \\
\hline \multicolumn{4}{|c|}{ Demographic Variables } \\
\hline GENDER & $(0=$ Male, $1=$ Female $)$ & .175 & .380 \\
\hline CHILDREN & $\begin{array}{l}\text { Children age } 12 \text { or under at home }(1=\text { yes, } \\
0=\text { no })\end{array}$ & .370 & .483 \\
\hline MOTHER & Interaction term (GENDER*CHILDREN) & .013 & .115 \\
\hline SALARY & Monthly salary in 10,000 Yen & 17.428 & 5.503 \\
\hline EDUC & $\begin{array}{l}(1=\text { Compulsory, } 2=\text { High School, } 3= \\
\text { College })\end{array}$ & 2.106 & .999 \\
\hline AGE & Age in years & 34.890 & 9.975 \\
\hline MBRYRS & Number of years as a union member & 11.853 & 7.786 \\
\hline ORGTEN & Company tenure, in years & 12.555 & 8.198 \\
\hline \multicolumn{4}{|c|}{ Job-Related Variables } \\
\hline EXTSAT & $\begin{array}{l}\text { A 7-item 5-point scale measuring extrinsic } \\
\text { satisfaction (e.g., pay) }(\alpha=.80)\end{array}$ & 2.807 & .561 \\
\hline INTSAT & $\begin{array}{l}\text { A 12-item 5-point scale measuring intrinsic } \\
\text { satisfaction (e.g., work itself) }(\alpha=.75)\end{array}$ & 3.184 & .438 \\
\hline EASEEXIT & $\begin{array}{l}\text { A single-item 5-point scale measuring per- } \\
\text { ceived ease of finding alternative employ- } \\
\text { ment }(1=\text { difficult, } 5=\text { easy })\end{array}$ & 2.933 & .947 \\
\hline Status & $\begin{array}{l}\text { Assistant foreman, foreman, assistant section } \\
\text { chief, section chief, or manager }(1=\text { yes, } 0 \\
=\text { no })\end{array}$ & .216 & .412 \\
\hline \multicolumn{4}{|c|}{ Union Attitudes } \\
\hline ATTULDRS & $\begin{array}{l}\text { A 4-item 5-point scale measuring favorable } \\
\text { attitude toward union leaders (e.g., effective, } \\
\text { caring) }(\alpha=.81)\end{array}$ & 3.301 & .713 \\
\hline IDUNION & $\begin{array}{l}\text { A 4-item 5-point scale measuring identifica- } \\
\text { tion with the local union (e.g., shared values, } \\
\text { concern for union's fate) }(\alpha=.61)\end{array}$ & 2.978 & .566 \\
\hline INSTRUMT & $\begin{array}{l}\text { A } 5 \text {-item } 5 \text {-point scale measuring perceived } \\
\text { value of unionism (e.g., useful communica- } \\
\text { tion channel, gains possible by staying a mem- } \\
\text { ber }(\alpha=.61)\end{array}$ & 3.265 & .513 \\
\hline \multicolumn{4}{|c|}{ Group Association Variables } \\
\hline WKGROUP & $\begin{array}{l}\text { A } 5 \text {-item 5-point scale measuring the degree } \\
\text { of social integration in the workplace (e.g., } \\
\text { feeling accepted and trusted by workgroup } \\
\text { members, making personal sacrifices for the } \\
\text { group) }(\alpha=.65)\end{array}$ & 3.393 & .514 \\
\hline \multicolumn{4}{|c|}{ Control Variables } \\
\hline QUMREL & $\begin{array}{l}\text { An } 8 \text {-item 5-point scale measuring percep- } \\
\text { tions of the quality of union-management re- } \\
\text { lationships (e.g., union and management are } \\
\text { responsible and cooperative and share mu- } \\
\text { tual trust) }(\alpha=.81)\end{array}$ & 3.282 & .520 \\
\hline MPLANT & $\begin{array}{l}\text { A dummy variable indicating whether the } \\
\text { worker was in the main plant of the organi- } \\
\text { zation }(1=\text { yes, } 0=\text { no })\end{array}$ & .739 & .439 \\
\hline LNUSIZE & $\begin{array}{l}\text { Natural log of union size (number of union } \\
\text { members) }\end{array}$ & 7.208 & 1.420 \\
\hline
\end{tabular}


Table 2. Determinants of Union Participation: Ordinary Least Squares Estimates.

\begin{tabular}{|c|c|c|c|}
\hline $\begin{array}{l}\text { Independent } \\
\text { Variable }\end{array}$ & $\begin{array}{l}\text { Hypothesized } \\
\text { Direction }\end{array}$ & $\begin{array}{c}\text { Parameter } \\
\text { Estimate }\end{array}$ & $\begin{array}{c}\text { Std. } \\
\text { Error of } \\
\text { Estimate }\end{array}$ \\
\hline Intercept & & .094 & .102 \\
\hline \multicolumn{4}{|l|}{ Demographics } \\
\hline GENDER & - & -.019 & .027 \\
\hline CHILDREN & - & $.095^{* * *}$ & .020 \\
\hline MOTHER & - & $-.197 * *$ & .076 \\
\hline SALARY & + & $.021^{* * *}$ & .003 \\
\hline EDUC & + & $-.032 * * *$ & .010 \\
\hline AGE & + & $-.005^{* * *}$ & .001 \\
\hline MBRYRS & + & $.012 * *$ & .004 \\
\hline ORGTEN & + & $.008^{*}$ & .004 \\
\hline \multicolumn{4}{|c|}{ Job-Related Variables } \\
\hline EXTSAT & - & $-.097 * * *$ & .020 \\
\hline INTSAT & + & -.006 & .025 \\
\hline EASEEXIT & - & -.006 & .009 \\
\hline STATUS & + & -.018 & .023 \\
\hline \multicolumn{4}{|l|}{ Union Attitudes } \\
\hline ATTULDRS & + & $.152 * * *$ & .016 \\
\hline IDUNION & + & $.298 * * *$ & .019 \\
\hline INSTRUMT & + & $.160^{* * *}$ & .020 \\
\hline \multicolumn{4}{|c|}{ Group Associations } \\
\hline WKGROUP & + & $.177 * * *$ & .018 \\
\hline \multicolumn{4}{|l|}{ Control Variables } \\
\hline MPLANT & + & $.308 * * *$ & .020 \\
\hline QUMREL & + & $.092 * * *$ & .021 \\
\hline LNUSIZE & - & $-.022 * *$ & .006 \\
\hline R-Square & .361 & & \\
\hline Adj. R-Square & .360 & & \\
\hline $\mathrm{N}$ & 6651 & & \\
\hline
\end{tabular}

* Significant at the .05 level; ** at the .01 level; $* * *$ at the .001 level.

\section{Discussion}

Our finding of significant effects of pay and tenure on union participation are consistent with our knowledge of Japanese society and employment and also consistent with results obtained in the West. The results underscore the traditional Japanese hierarchical workplace order, in which control is wielded by senior workers who simultaneously play the role of supervisors and tend to subordinate young union leaders (Ishikawa 1984). As in the West, long-term members may be more likely to be union activists because they understand management issues better than members with less tenure. Alternatively, senior members may be more likely to be elected union leaders if workers perceive them to have more credibility with management. Contrary to Western findings, and also somewhat surprising in view of the widely noted respect for age in Japan, we find that age was associated with lower participation.

The positive relationship between the presence of young children and union participation for men is also contrary to Western results. In the West, a significant negative relationship has usually been found, and researchers have speculated that the presence of young children inhibits participation due to time constraints. In Japan, it may be that men with young children have a greater stake in their job than do men without children, and hence participate in the union in order to protect their interests. This effect may be stronger in Japan than in the West due to greater sex-role stereotyping and more restricted interfirm mobility in Japan.

The finding of less participation by women with young children is as expected. The lack of a significant direct relationship between gender per se and union participation, however, is surprising and also inconsistent with Western findings. One possible explanation is that most Japanese unions have women's divisions in which women are encouraged to participate (Cook and Hayashi 1981). This result may also reflect, to some extent, the changing attitudes of Japanese women regarding work (Okubayashi 1986), or a growing stake in their jobs. Okubayashi (1986) noted that $55 \%$ of women surveyed in 1983 intended to continue working after marriage and children, and only $19 \%$ intended to leave the labor market after marriage.

In contrast to some Western findings (McShane 1986a), education was negatively related to participation in this sample. This result may be partly attributable to recent changes in the social outlook of the younger generation of college graduate employees relative to the social outlook of traditional collective-minded blue-collar workers. That is, these new workers (shin-jinrui, or "new human be- 
ings," loosely translated as "yuppies") pay more attention to self-realization and personal fulfillment than to job security, pay, and working conditions (Ishikawa 1984). Note that McShane's positive direct effect for education on administrative union participation was partially offset by negative indirect effects in his path model results. Considering this point in conjunction with differences in dependent and independent variables and samples, the negative net effect for education found here may not be as striking a contrast to Western findings as it appears at first blush.

The negative relationship between extrinsic satisfaction and participation suggests that increased dissatisfaction with pay and working conditions leads to greater participation, a result that agrees with persistent Western findings. In addition, it implies that workers view these unions as having the ability to make suitable alterations in pay and working conditions at the plant. Thus, there does appear to be some perceived "payoff" to participation in Japanese unions, lending support to what Klandermans called rational choice theory. The absence of a relationship between intrinsic satisfaction and union participation, which is inconsistent with some Western results (Nicholson, Ursell, and Blyton 1981), may indicate that unions are seen as instrumental primarily in terms of workers' extrinsic job concerns.

In contrast to the persistent findings in the West, in this sample job status did not have a strong relationship with union participation. This result likely reflects the intricacies of tōkyū shikaku seido mentioned earlier in this paper, but it could also reflect the weak "status position" in the Japanese organization; status loses its substantial meaning after its correlates (age, gender, education, tenure, and pay) are controlled for.

In general, the results of the union attitude variables suggest that attitudes toward one's union may be better predictors of participation than demographic or job-related variables. These results are entirely consistent with many Western findings (for example, Anderson 1979; Huszczo 1983; Nicholson, Ursell, and Blyton 1981).

The results for the interaction with group members variable (WKGROUP) suggest that the greater the degree of interaction within the group, the more likely a member will participate in union activity. This result is consistent with previous Western findings (McShane 1986b), and reinforces Strauss's (1977) emphasis on the occupational community.

The positive relationship between perceptions of union-management relationship quality and participation is consistent with the increasing use of joint consultation in Japan. Ishikawa (1984) noted that by $1970,90 \%$ of all large and mediumsized firms in the Japanese public sector had established joint consultation programs. In an enterprise union situation, collective bargaining and joint consultation are carried out by the same actors (Ishikawa 1984).

As with union size, the significant relationship we find between participation and working in the main plant of the organization suggests that negotiations and major union activity are centered around the main plant. Union members in satellite plants may perceive less of a payoff to participation.

\section{Conclusion}

We have attempted to determine whether Western models of union participation are applicable to Japan. Generally, the specification used in this paper succeeds in providing results consistent with those obtained in the West. All three of Klandermans' (1986) theories of participation find some potential support in these results, indicating, as Klandermans suggested, that those theories are complementary rather than competitive, and that comprehensive approaches are therefore needed.

The main purpose of this paper, however, was not to test the comparative validity of different Western theories of participation, but rather to gauge the general applicability of Western theories 
to Japan. Although there are certainly some aspects of industrial relations that vary from culture to culture, the evidence we have presented suggests that the determinants of union participation have some universality. In Cole's (1972) terms, our results lend support to the "structuralist view." That is, union participation and other industrial relations phenomena in Japan may become more similar to those in the West as Japan's industrial structure becomes more similar to those of advanced Western nations. The similarity between our findings for Japan and other researchers' findings for Western countries, particularly in terms of the relationships between union participation and demographics, job-related variables, and group associations, underscores the similarities between Japan and the West. The strong relationships we find between unionrelated variables and participation also parallel Western findings, but since strong relationships of this type seem almost inevitable, it is not clear that they provide a strong test of cross-cultural transferability. Even so, there is much in our results to support the structuralist viewpoint, and little to support the alternative "culturalist" view, which attributes international differences to unique historical and value orientations.
In some respects, however, our results are at odds with most Western literature. The negative effects on union participation of education and age, and the absence of job status effects, are unexpected. These results could reflect unique cultural factors such as the increasing proportion of college graduates who have a different social outlook, overwhelming tenure influences that wash away age effects, and the weak status effect once its correlates are controlled for. Another possible explanation is that previous Western research has underspecified the model. For example, has previous research incorrectly attributed a positive participation effect to age due to a failure to control for union and company tenure? Similarly, has the status effect been properly identified in past studies, or have they failed to control for the effects of other factors associated with the status variable? In addition, the close ties between the organization and the individual as noted by Shirai $(1983: 129)$ and the strong results we find for union attitudes suggest that organizational factors have an important influence on participation in the union. Thus, the results from this study of union participation in Japan are suggestive of some paths of research that might be useful in studies of the topic in Western economies. 


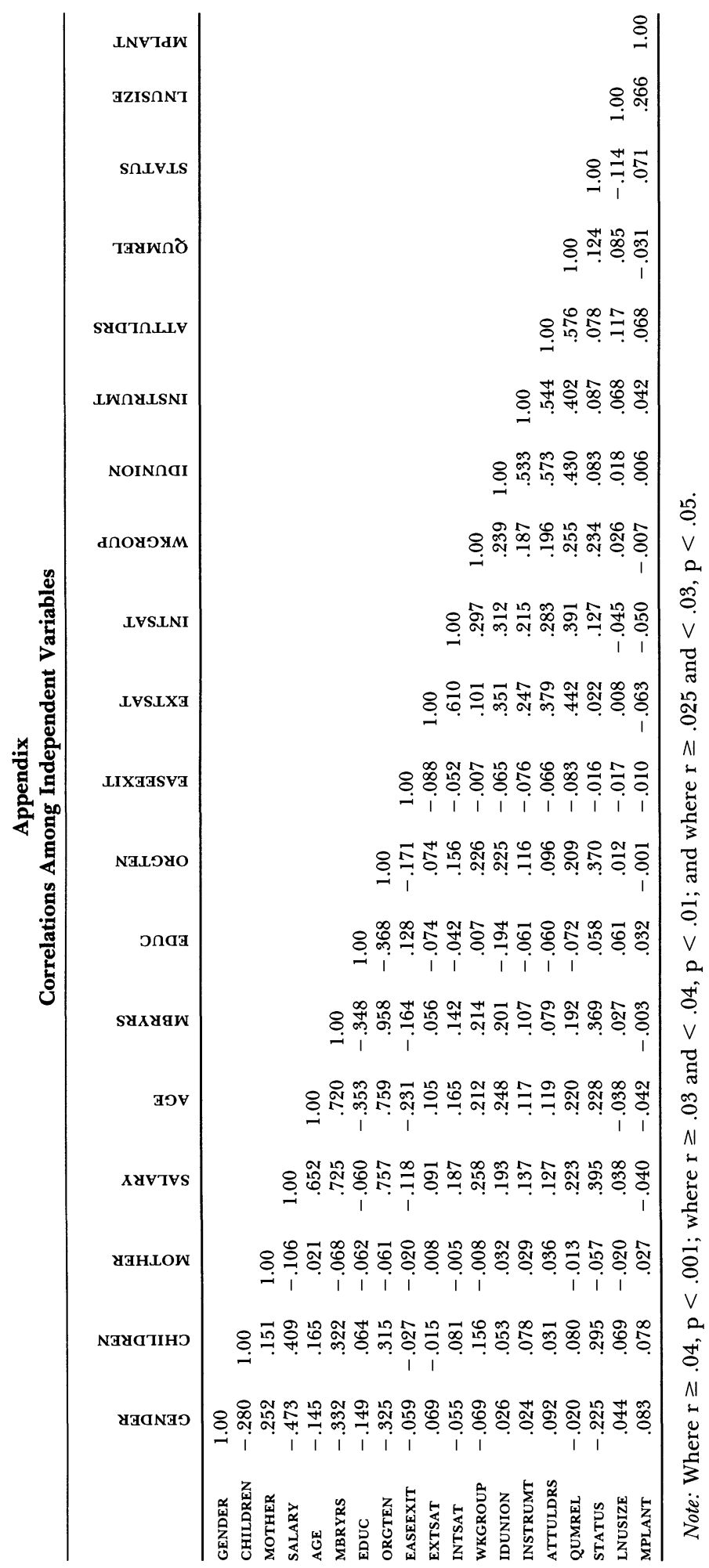




\section{REFERENCES}

Abdel-khalik, A. Rashad. 1988. "Hierarchies and Size: A Problem of Identification." Organization Studies, Vol. 9, No. 2, pp. 237-51.

Ahmed, Zubeida L. 1984. "Women's Work and Their Struggle to Organize." Development, No. 4, pp. 36-40.

Anderson, John C. 1979. "Local Union Participation: A Reexamination." Industrial Relations, Vol. 18, No. 1 (Winter), pp. 18-31.

Ayusawa, Iwao. 1962. Organized Labor in Japan. Tokyo: The Foreign Affairs Association of Japan.

Bandō, Satoshi. 1981. "Qualitative Change in the Labor Movement." Japan Echo, Vol. 3, No. 1 (Spring), pp. 30-37.

Blau, Peter M. 1970. "A Formal Theory of Differentiation in Organizations." American Sociological Review, Vol. 35, No. 2 (April), pp. 201-18.

Chacko, Thomas I. 1985. "Member Participation in Union Activities: Perceptions of Union Priorities, Performance and Satisfaction." Journal of Labor Research, Vol. 6, No. 4 (Fall), pp. 363-73.

Cole, Robert E. 1970. "Japanese Workers, Unions, and the Marxist Appeal." The Japan Interpreter, Vol. 5, No. 2 (Summer), pp. 114-34.

1972. "Permanent Employment in Japan: Facts and Fantasies." Industrial and Labor Relations Review, Vol. 26, No. 1 (October), pp. 615-31.

Cook, Alice H., and Hiroko Hayashi. 1981. Japanese Working Women: Discrimination, Resistance, and Reform. Ithaca, N.Y.: ILR Press.

Dewar, Robert, and Jerald Hague. 1978. "Size, Technology, Complexity, and Structural Differentiation: Toward a Theoretical Synthesis." Administrative Science Quarterly, Vol. 23, No. 1 (March), pp. 111-36.

Form, William H. 1973. "Job vs. Political Unionism: A Cross National Comparison." Industrial Relations, Vol. 12, No. 2 (May), pp. 224-38.

Furuya, Ken'ichi. 1980. "Labor Management Relations in Postwar Japan: Their Reality and Change." Japan Quarterly, Vol. 27, No. 1 (January-March), pp. 29-38.

Glick, William, Phillip Mirvis, and Diane Harder. 1977. "Union Satisfaction and Participation." Industrial Relations, Vol. 16, No. 2 (May), pp. 145-51.

Hanami, Tadashi. 1979. Labor Relations in Japan Today. Tokyo: Kodansha International.

Hayashi, Hiroko. 1985. "Japan." In J. Farley, ed., Women Workers in Fifteen Countries. International Industrial and Labor Relations Report Number 10. Ithaca, N.Y.: ILR Press, pp. 57-67.

Hoyman, Michele M., and LaMont Stallworth. 1987. "Participation in Local Unions: A Comparison of Black and White Workers." Industrial and Labor Relations Review, Vol. 40, No. 3 (April), pp. 323-35.

Huszczo, Gregory E. 1983. "Attitudinal and Behavioral Variables Related to Participation in Union Activities." Journal of Labor Research, Vol. 4, No. 3 (Summer) pp. 289-97.

Ishikawa, Akihiro. 1984. "Japanese Trade Unionism in a Changing Environment." Industrial Democracy, an International Social Science Journal, Vol. 36, No. 2, pp. 272-83.

Klandermans, Bert. 1986. "Psychology and Trade Union Participation: Joining, Acting, Quitting." Journal of Occupational Psychology, Vol. 59, No. 3 (September), pp. 189-204.

Kochan, Thomas A. 1978. "Contemporary Views of American Workers Toward Trade Unions." Research Report to the Department of Labor. Washington, D.C.: GPO.

Kolchin, Michael G., and Thomas Hyclak. 1984. "Participation in Union Activities: A Multivariate Analysis." Journal of Labor Research, Vol. 5, No. 3 (Summer), pp. 255-61.

Koshiro, Kazutoshi. 1980. "Perceptions of Work and Living: Attitudes of the Japanese." Japan Quarterly, Vol. 27, No. 1 (January-March), pp. 46-54.

Lassewell, Thomas E., John H. Burma, and Sidney H. Aronson. 1965. Life in Society. Chicago: Scott, Foresman.

McShane, Steven L. 1986a. "A Path-analytic Study of Participation in Union Administration." Industrial Relations, Vol. 25, No. 1 (Winter), pp. 72-80.

1986b. "The Multidimensionality of Union Participation." Journal of Occupational Psychology, Vol. 59, No. 3 (September), pp. 177-87.

Mills, Daniel Quinn. 1986. Labor-Management Relations. New York: McGraw-Hill.

Naitō, Norikuni. 1983. "Trade Union Finance and Administration." In Taishirō Shirai, ed., Contemporary Industrial Relations in Japan. Madison, Wis.: University of Wisconsin Press, pp. 145-59.

Nicholson, Nigel, Gill Ursell, and Paul R. Blyton. 1981. The Dynamics of White Collar Unionism. London: Academic Press.

Nicholson, Nigel, Gill Ursell, and Jackie Lubbock. 1981. "Membership Participation in a White Collar Union." Industrial Relations, Vol. 20, No. 2 (Spring), pp. 162-78.

Odaka, Kunio. 1975. Toward Industrial Democracy: Management and Workers in Modern Japan. Cambridge, Mass.: Harvard University Press.

Oh, Tai K. 1976. "Japanese Management: A Critical Review." Academy of Management Review, Vol. 1, No. 1 (January), pp. 14-25.

Okubayashi, Kōji. 1986. "Recent Problems of Japanese Personnel Management." Labour and Society, Vol. 2, No. 1 (January), pp. 17-38.

Perline, Martin, and V. R. Lorenz. 1970. "Factors Influencing Participation in Trade Union Activities." American Journal of Economics and Society, Vol. 29, No. 4 (October), pp. 425-37.

Portwood, James D., David Pierson, and Stuart M. Schmidt. 1981. "When Less Is More: A Study of the Participation/Satisfaction Relationship in Unions." Proceedings of the Forty-first Annual Meeting of the Academy of Management (San Diego, August 2-5, 1981). Wichita, Kans.: Academy of Management, pp. 276-80.

Sano, Yōko. 1977. "Seniority Based Wages in Japan: A Survey." Japanese Economic Studies, Vol. 5, No. 3 (Spring), pp. 48-65. 
Shirai, Taishirō. 1983. "A Theory of Enterprise Unionism." In Taishirō Shirai, ed., Contemporary Industrial Relations in Japan. Madison, Wis.: University of Wisconsin Press, pp. 117-45.

Spinrad, William. 1960. "Correlates of Trade Union Participation: A Summary of the Literature." American Sociological Review, Vol. 25, No. 2 (April), pp. 237-44.

Strauss, George. 1977. "Union Government in the U.S.: Research, Past and Future." Industrial Relations, Vol. 16, No. 2 (May), pp. 215-42.

Sundström, Marianne. 1982. "Part-time Work and Trade Union Activities Among Women." Economic and Industrial Democracy, Vol. 3, No. 4 (November), pp. 561-67.

Taira, Koji, and Solomon B. Levine. 1985. "Japan's Industrial Relations: A Social Compact Emerges."
In Hervey Juris, Mark Thompson, and Wilbur Daniels, eds., Industrial Relations in a Decade of Economic Change. Madison, Wis.: Industrial Relations Research Association, pp. 247-300.

Tannenbaum, Arnold S., and Robert L. Kahn. 1958. Participation in Union Locals. Evanston, Ill.: Row, Peterson.

Troy, Leo, and Neil Sheflin. 1985. U.S. Union Sourcebook: Membership, Structure, Finance. West Orange, N.J.: Industrial Relations Data and Information Services.

Van Helvoort, Ernest. 1979. The Japanese Working Man: What Choice, What Reward? Vancouver: University of British Columbia Press.

Vogel, Ezra F. 1971. Japan's New Middle Class: The Salary Man and His Family in a Tokyo Suburb. Berkeley: University of California Press. 